\title{
Patriotism, Weapons Fetishism and Accountability: An Examination of the U.S. UAV Program
}

\author{
Binoy Kampmark
}

\begin{abstract}
Ubi cessat remedium ordiniarium, ibi decurritur ad extraordinarium Where the ordinary remedy fails, recourse must be had to an extraordinary one

(Beres, 2011: 93)
\end{abstract}

In war, the technological imperative often trumps the legal one. This has been starkly illustrated in the legal and policy debates surrounding the use of unmanned vehicles, more popularly termed drones, in conflict. The US example on this score is particularly relevant. This paper argues that the drone program has been assimilated as a feature of what might be termed technological patriotism. This is characterised by a form of weapons fetishisation, by which the drone is deemed a supreme object of post-September 2001 conflicts. Such patriotism, as a consequence, is distorting. American citizens accused of committing terrorist attacks may be attacked and assassinated without due process. Constitutional protections are sidestepped, and justified on the basis of self-defence and the nature of the conflict. Accountability for such actions is thereby minimised.

The use of drones against citizens and non-citizens became a feature of US military policy under both the Bush and Obama administrations. Indeed, it has been argued that the use of such technology has far exceeded narrow legal directives about their deployment. "Drones, assumed for the purposes of the present report to be armed drones, have moved from the horizon into the realm of the known" (Heynes 2013: para 37). The passage by Congress of the Authorisation for the Use of Military Force in 2001 paved the way for the use of drones as part of the US policy, an expansive vesting of power that continues to blur the policy and legal context as to how it is used (US Congress 2001; Miller and DeYoung 1999).

Since then, the mechanised killing of human targets via the remote controlled means of bases in the US has become a matter of considerable debate domestically and beyond. In historical terms, it reaffirms the tendencies of states to greater states of automation in war, a theme underscored by Martin van Creveld (1989). The impact of such technology was made evident in 2013, when a debate was sparked as to whether Apple would accept Josh Begley's Drones app, which would notify users whenever a US drone strike was reported. It was rejected no less than three times (Gregory 2014).

The faith shown by American citizens in the drone program of the Obama Administration has increased with announcements that Washington's enemies are being disposed of with efficient and rapid ease. A study by the Pew Research Centre in 2013 suggested that the US ranked second after Israel in terms of popular approval for the use of drones, registering a figure of 61 percent (Drake 2013). The killing of the Islamic militant and US national, Anwar al-Awlaki[2], said to be behind shootings at Fort Hood, the Christmas "underwear bomber" incident, and an attempt to bring down a cargo aircraft using explosives in toner cartridges, was far from universally condemned for breaching matters of due process (The Economist 2013).

Supporters argue that it is clean, efficient and humanitarian in so far as it is specific in its targeting. Opponents argue that it places the US on a dangerous path, making the use of such weapons convenient and expedient, while 
exaggerating their tactical effectiveness. What this paper argues is that the use of drones has become a fetish of the US military and foreign policy, one that is typical of the smugness that accompanies notions of "projecting power without vulnerability" (Gregory 2014). It signals the dangers inherent in the use of various military technologies which undermine legal rules while constituted as an essential part of the military industrial complex. The term suggested here is that of technological patriotism. First, a discussion of the technological idealisation behind such weapons is undertaken. Then, the complexity of weapons fetishism is examined in detail. The historical roots of this tendency are also considered with special reference to the US Atomic and Nuclear Program. This paper argues that an understanding of those links is useful in assessing the US military complex in terms of what weapons it embraces, and how such deployment is rationalised.

\section{| Situating Technology and Culture}

Understanding drone culture in the US military establishment requires a broader discussion about the connections between warfare and patriotic identities. The resort to technological expertise as argued by Mark Mazetti (2013) tends to be privileged over human intelligence. The wedding of technology to patriotism is a constant feature of warfare and nationalism, though this came into its own during the twentieth century with the emergence of concentrated military complexes. Jack Snyder has argued that a "strategic culture" may well be discernible in certain contexts when examining such phenomena, something he employs with good measure when examining Soviet attitudes to limited nuclear conflict (Snyder 1977; MacMillan et al 1999). The logical assertion has not gone unnoticed in military courses, where culture features as a component of the curriculum.[3]

John Somerville considers the links between weapons and patriotism, the former being a neat functioning of the latter. Until the World Wars, weapons, in terms of characteristics and types, bore "only a technical relationship to patriotism" (Somerville 1981: 568). The greatest example in the twentieth century was how the construction and use of the atomic bomb against Japan became a patriotic assertion, even obsession. As Denise Kiernan (2013) shows, female employees on the Manhattan project were encouraged that their work would lead to a quicker end to the war. Other examples show that the patriotic project did not merely cut across the sexes, but also the races (Kinchy 2009). As John Dower (1997) explains, this narrative was "triumphal" and "heroic," and one that was strongly developed by one of the first eloquent exponents of the military industrial complex - the scientist James Conant (Dower 1996).

While there was also a terror of the atomic bomb after the end of the Second World War, Boyer notes that horror, by the 1950s, "had given way to an interval of diminished cultural attention and uneasy acquiescence in the goal of atomic superiority over the Russians" (Boyer 1994: 352). Security came first and battlefield ethics were left lagging. Opposition to the use of such weapons was carpeted as a matter of dangerous, if not delusionary, pacifism. The evolution of attitudes to the weapon had come full circle. "The dreaded destroyer of 1945 had become the shield of the Republic by 1950" (Boyer 1994: 349).

The shield of the republic produced a form of military fetishism. Critical theory sees this as a variant of product fetishism, or what Karl Marx termed "commodity fetishism." Marx has a specific reading of how this manifests, arguing that real social relations are effectively hidden in a process of objectification through human labour. What matters in this instance is attributed value, an "objective character stamped upon the product of that labour; because the relation of the producers to the sum total of their own labour is presented to them as a social relation, existing not between themselves but between the products of their labour" (Marx 1982: 308). It is precisely this "social relation" that is of interest here, in the values that are misattributed. And such fetishism as opposed to the use of weapons can also be found in the scholarship making use of Marx's theory, at least in part (De Santana 2009).

A body of work has emerged in critical theory examining the links between weapons and their associations with commodity theory. This is particularly relevant with the nuclear weapons establishment. According to Joseph Masco, nuclear weapons, or at the very least their possession, have been constituted as a social norm, "the preeminent national fetish of the United States." "Nuclear fetishism" has been suggested as a means of explicating the hollowness of deterrence theory, something that, in turn, builds upon critiques of international relations theory such as neorealism. [4] "Like commodities, weapons are sensuous things and at the same time supra-sensible or social. Their sensuous characteristics make them useful for exerting force" (De Santana 2009: 339). Nuclear weapons, when considered in terms of their social form of value or "property attributable to the network of social relations between states" is treated as if it were a natural feature of the physical substance of the weapon" (De Santana 2009: 339). Masco (2006) suggests that nuclear weapons are not commodities as such because they do not circulate, but the theoretical purview 
is useful to extend. The nuclear weapon is considered as ordering and mediating relations between states, generating a false hierarchy by virtue of possession. Those who have the weapons prevail over those who do not (Masco 2006; Wyn Jones 1999: 144; Luckman 1984).

Slavoj Žižek terms this "fetishistic misrecognition", something he employs to considerable effect in examining the concept of divine rule as a function of monarchy. "Being-a-king' is an effect of the network of social relations between a 'king' and his 'subjects'; but - and here is the fetishistic misrecognition - to the participants of this social bond, the relationship appears necessarily in an inverse form. They think that they are subjects giving the king royal treatment because the king is already himself, outside the relationship of his subjects, a king and as if the determination of 'being-a-king' were a 'natural' property of the person of a king" (Žižek 1989: 24; De Santana 2009: 338).

How lethal technologies can assume celebratory, even patriotic forms of identification is amply shown in the culture wars centred on commemorating the use of the atomic bomb five decades after the Hiroshima and Nagasaki bombings. Curators at the National Air and Space Museum in Washington, D.C. found themselves accused of being "revisionists" in attempting to show multiple representations of the bombings, including the suffering of the victims (Hubbard and Hasian 1998). A public relations campaign ensued, battling over the celebratory narrative of the role played by the bombing of Japan and the crewmembers, and the broader didactic purposes adopted by the curators on the consequences of using such weapons (Capaccio and Mohan 1995: 20; Hubbard and Hasian 1998: 497). Broader links and legacies were suggested in the initial version of the display "The Crossroads: The End of World War II, the Atomic Bomb and the Origins of the Cold War." While the dropping of the bombs by the Enola Gay was vital in ending the war, it also emerged out of a set of various strategic considerations, including Cold War calculations along the lines suggested by the historian Gar Alperovitz (1995). The bomb's deployment on Japan could not be divorced from the implications of the next great political rivalry.[5] Then, after months of acrimonious debate, the organisers gave it a new name: “The Last Act: The Atomic Bomb and the End of World War II." Finally, and suggestively, the entire commemorative base was shrunk, narrowed to one single focus: "The Enola Gay" (Nobile 1995; Linenthal and Engelhart 1996).

The reaction to the anniversary of the Hiroshima and Nagasaki bombings is a striking illustration of technological patriotism in action, one that subordinates and even erases victim narratives. The resulting Enola Gay display removed any reference to the Japanese perspective while featuring the pilot, Paul W. Tibbets, his crew and the aircraft as heroes. Visitors were treated to a 14-minute film focusing exclusively on their exploits (Meyer 1995: D1). This was certainly in line with the views of such individuals such as retired Major General Sweeney, who flew on both the Hiroshima and Nagasaki missions. For Sweeney, the moral demarcations in World War II were clear - the "Forces of evil were clearly defined" with an enemy that showed no intention of surrendering unconditionally (United States Senate 1995: 4-11). Portions of the Enola Gay were displayed, along with information on its restoration and general material on the Boeing B-29 Superfortress (Hubbard and Hasian 1998: 508).

The weapons and the crew became the symbolic referents of remote, effective and ultimately victorious actions, exhibited within a celebratory space that diminishes the humanity of the target. As the Assistant Director for Aeronautics at the National Air and Space Museum Thomas Crouch explained, both he and his curators had "failed to appreciate the deep and powerful links that bind the memory of the bomb to the incredible sense of joy and relief at the end of the war" (United States Senate 1995: 75).

The implications of the Enola Gay controversy in terms of how new weapons are justified as solutions to enduring problems are significant. Lethal technological supremacy allied to patriotic goals makes its deployment against human populations easier to justify. The constraints of the laws of war are lifted, giving way to other pressing considerations. Both John Dower (1986) and Ronald Takaki (1995), in examining the motivations behind the dropping of the atomic bombs, consider the racial dimension of the Pacific conflict. Indeed, Dower goes further in examining the psychopathology of war cultures that breeds folly and the broader indifference to suffering, and work that takes its cue from the Clausewitz claim that the "wish to annihilate the enemy's forces is the first-born son of war” (Dower 2010; Lacquer 2011). Takaki suggests, focusing primarily on President Harry S. Truman's psyche, that race and a language of "masculinity," along with his policymakers, figured prominently in the way the atomic bomb was viewed (Takaki 1995: 114-5).

\section{| Drones and Patriotism}

A modern application of the Enola Gay syndrome, with its shrinking focus on civilian deaths and its extolling of 
a patriotic machine quality, is amply demonstrated in discussions about the use of drones, which became significant after the attacks of September 11, 2001. It has even been argued, not entirely convincingly, that concepts such as "just war theory" prevailed with some force till the challenges posed by non-state actors in the wake of these coordinated attacks on the United States (Rengger 2002: 353). Officials within the Bush administration suggested that the nature of the war had altered the terrain of response. The US military would, in the words of Vice President Dick Cheney, "have to work... sort of on the dark side" and "a lot of what needs to be done here will have to be done quietly, without any discussion, using methods that are available to our intelligence agencies to use any means at your disposal to achieve our objective" (Paust 2007: 12).

Parallels with the use of atomic weapons on Japan were even noted. Andrew Battista (2012), writing for North of Centre, a paper based in Lexington, Kentucky, found echoes in the way atomic bombs were deployed against the Japanese and the use of drone warfare in targeting militants. "The United States entertains the fantasy that it can make unilateral decisions about who lives and dies, all the while waging clean wars in which American lives are preserved and 'the bad guys only' are surgically removed from existence."

The embrace of the drone warfare program, deemed an effective, constructive killing system, has all the features of such fetishistic misrecognition. It renders such devices mysterious in the Marxist sense; and it obscures the social relations in the sense Žižek describes it, thereby making it attractive and, as the Obama administration has shown, unimpeachable as policy.

Significantly, in the manner described by Masco on the appraisal of nuclear weapons, it has the potential to become a social norm, a fetish amongst those of the security establishment. This is certainly the case amongst strategists and military adherents who have been debating amongst themselves the utility of such a program.

The overwhelming sense here is that faith placed in such technology has a displacing effect on rights, while it fetishizes the "procedure over complexity and intention over effects" (Burke 2004). Frank Sauer and Niklas Schöring consider that such forms of unmanned technology have proven to be attractive to democracies. The authors draw the conclusions that democracies can also be aggressive and do not "naively" take their "general peacefulness at face value." In fact, the use of unmanned vehicles has a special appeal for democracies, constituting a "silver-bullet" that might well backfire (Sauer and Schöring 2012).

The consequences of such a misrecognition, as described by Žižek, do more than obscure the objective framework of relations between the subjects vis-à-vis the use of drones. It is fatal to justice and the constitutional system that mandates the importance of due process. The weapon's use and value dispenses with the need to take judicial measures, relying, instead, in a field of extra-judicial rationale. In a sense, the use of the weapon exacts a just retribution, a form of de-facto justice that exists outside judicial strictures and procedures. Some of these are discussed in detail by Michael J. Boyle (2013). Suggestions have been made that such drone operations are effectively resulting in "blow back" operations against American interests, typified by the testimony of Pakistani American Faisal Shahzad who attempted to bomb a busy intersection in Times Square, New York. Drones, argued Shahzad "don't see children, they don't see anybody. They kill women, children, they kill everybody. It's a war and in war, they kill people. They're killing all Muslims" (noted in Boyle 2013: 1).

The value of drones in eliminating targets is extolled in various US military reports that emphasise its distinct advantages. They perform what has come to be known as the three "Ds": dirty, dull and dangerous tasks while also conforming to what is deemed as "light footprint" counter-terrorism (DOD 2007: 19). This reflects a broader tendency in the US armed forces to move to increasingly robotic forms of war where human agency is distanced from the scene of combat. According to Peter Singer, former Defence Department employee and advisor to President Obama's election campaign, robotic systems have proliferated. None were used when the US forces invaded Iraq in 2003. Six years later, there were 12,000 "robotic systems" performing 33,000 missions a year (Singer 2009). With the emergence of such technologies, "cubicle warriors" are becoming the norm even as the weapon is being fetishised (Shaw and Akhter 2012). Jacob Wood and Ken Harbaugh (2014) initially believed that such systems would not "do anything more than augment the manned systems that provide aerial reconnaissance and close air support for troops on the ground. We took it for granted that humans on the front lines would always play the lead role."

Just as nuclear weapons were normalised in US strategic thinking to the point that their tactical use could be considered feasible, and even necessary, drone technology is similarly assimilated into military orthodoxy. Criticisms about its use are deemed far-fetched and misplaced. Benjamin Wittes, Senior Fellow of Governance Studies at the Brookings Institute, insists that the Obama administration's approach to drone warfare has been misread, with commentaries casting "it in a far more menacing light than its rather restrained reality justifies" (2013). The administration was not "claiming undue power" in using such technology. Indeed, some analysts argue that UAVs 
and their availability impose a moral duty to use them, an argument that has also been used in terms of employing extraordinary weapons to prevent the prolongation of war (Strawser 2010). There is "no need for special ethical concern for this weapons system as opposed to any other more standard weapon technology." What the use of drones suggests is a historical continuation of a project of "removing a warrior even farther from his foe for the warrior's better protection" (Strawser 2010: 343).

Drone technology has been deemed a natural extension of principled American power. Senator Eric Cantor made this position clear in a statement sympathetic to its use. Technological supremacy was indispensable for the assertion of American power, and a principled one at that. "If we're going to continue to be the leading force for peace, prosperity and security in this world, we're going to have to have the tools necessary to do so." Such technology need not be contrary to morality, ethics or law. "And I believe, just as in the prior administration, this administration - we can strike that balance to protect America, to employ technologies to do that, at the same time upholding constitutional rights" (Cantor quoted in Beattie 2013).

Consequences are thereby obscured in favour of procedural assumptions. In a study on the strategic context of drones, the authors acknowledge the support that drones can give forces engaged in "seizing territory or disrupting terrorist organisations. However, when drones are no longer part of the framework but rather supplant the framework and become the strategy entirely, they can have serious political blowback." (Foust and Boyle 2012)

The rationalisation of such supplanting frameworks is evident in the justifications for the lethal use of drones outlined by Harold Hongju Koh, formerly legal advisor to the State Department and Sterling Professor of International Law at Yale University. He deals with the policy of targeting and the weapons system used to attain that goal. Koh insists that the "very use of advanced weapons systems" is not the issue - the rules of targeting do not hinge on the type of system used. Pilotless aircraft or smart-bombs fall into the same category. The issue rather is that "they are employed in conformity with the applicable laws of the law" (Koh 2010). Dispensing with the issue of discussing the weak security environment within which the weapons system is used, Koh assumes that the laws of war are abided by in using them. Technological failure and intelligence gaps are ignored.

Deploying such weapons extraterritorially in Pakistan, Somalia and Yemen has given some commentators cause for concern. A potential "global drone war" is in the making (Morely 2012). This does not bother such defenders of the drone policy such as Tom Rogan of the conservative National Review, who sees sovereignty - American sovereignty at least - as necessarily expansive. Unmanned weapons systems simply prove valuable in advancing the concept. In the case of Pakistan, for instance, the United States is using drones both with, and without consent, against an enemy which is both battled and supported by Karachi. "An expansive notion of extra-territorial selfdefence is intrinsic to a counterterrorism policy that's rational" (Rogan 2013). Rogan himself is something of a technological patriot, seeing the remote weapons system as actually compliant with "humanitarian norms".

The illusion of total effectiveness in using such weapons is also encouraged, despite the fact that drone technology is marred by faulty intelligence and poor means of detection (Voice of America 2013). "What the public needs to understand is that the video provided by a drone is not usually clear enough to detect someone carrying a weapon, even on a crystal-clear day with limited cloud and perfect light" (Linebaugh 2013).

Technological patriotism in general is malleable in its construction around humanitarianism and the mitigation of civilian casualties. It ignores those attitudes outlined by former Reagan official and Assistant Secretary of the Treasury for Economic Policy Paul Craig Roberts, who sees such drone culture as lethal and expansive. "We are now witnessing the expansion of Obama's Kill List. The list began under the Bush regime as a rationale for murdering suspect citizens of countries with which the US was not at war. The Obama regime expanded the scope of the list to include the execution, without due process of law, the US citizens accused, without evidence presented in court, of association with terrorism. The list quickly expanded to include the American teenage son of a cleric accused of preaching Jihad against the West. The son's 'association' with terrorism apparently was his blood relationship to his father" (Roberts 2013).

Another former Reagan official, Lawrence J. Korb, who was Assistant Secretary of Defence, has advanced the idea that a potential misuse of robotics will do the reverse as to what Cantor suggests, namely "undermine our moral standing, and the US can't be a global leader without such standing” (Olsen 2010). The UN Rapporteur, Heyns, makes a similar point. Drones, he argues, are proving too good to resist, a drug of security and military application. "Given that drones greatly reduce or eliminate the number of casualties on the side using them, the domestic constraints - political and otherwise - may be less restrictive than with the deployments of other types of armed force. This effect is enhanced by the relative ease with which the details about the drone targeting can be withheld from the public eye and the potentially restraining influence of public concern. Such dynamics call for a heightened 
level of vigilance by the international community concerning the use of drones" (Heynes 2013: paragraph 18).

Such patriotism also ignores the culpability of the operator, the moral dilemma of the human behind the distant operating system, and its consequences. Beres provides a meditation on the subject, arguing that, "The overriding problem of international law enforcement is not that of Hostes humani generis, but rather the 'normal' human being, who adheres closely to most societal expectations, while secretly dreaming of corpses." Accordingly, that ordinary person is the creature behind "the past century's words crimes of war, terrorism, crimes against peace and crimes against humanity” (Beres 2011: 146).

The expansion of a law enforcement mechanism that employs assassination techniques by drone and extra surveillance satisfies this premise all too clearly. Individuality, suggests Beres is escaped through acts of collective violence, a sickness of the soul that finds form in killing outsiders. Suggestively, Beres speaks of these beings, having refused individuality, as themselves being robotic in inclination (2011: 147). Fitting, perhaps, is that this observation be taken further, to imply that highly defined technologies do have their role in overriding the very individualism that is repudiated by those who believe in collective violence. One robotic instinct confronts another, and the process of de-humanisation comes full circle. "Thus," writes Marge Van Cleef, "the illusion is promulgated that war can be waged with no domestic cost except the dehumanisation of US military people and the civilians who accidentally happen to be in the wrong place when the attack comes" (2010: 20).

\section{Drones and Forms of Americanness}

The fixation with drones and their use as extra-judicial killing machines has had another effect. It has stimulated a titanic contest between the security and legal establishments as to how Americanness is to be determined before robotic, drone technologies. Will a citizen's status matter in debates about how such weapons are used, notably in foreign theatres? The legal context of this is difficult enough as it is, seeing as the term "targeted killing" resists the definition of international law and has proven to be a fuzzy concept in US legal discourse. As Alston has explained, it is not a term of art in international law, nor does it "fit neatly into any particular legal framework" (2010: 4). One thing however, is clear. In Richard Miniter's words, "For the first time since the days of Abraham Lincoln, an American president has ordered the killing of a US citizen, far from any battlefield or courtroom” (Miniter 2011).

Legal attempts to bar listings of Americans on the CIA's terrorist target list have been rejected. Koh, in his address before the American International Law Society, did not see nationality as a shield - "individuals who are part of such an armed group are belligerents and, therefore, lawful targets under international law (2010). Nor were there bars at either international or domestic level on targeting and assassinating figures. A state "engaged in armed conflict" was not encumbered with any need to "provide targets with legal process before the state may use lethal force." (Again, faith in the extreme utility of surveillance and targeting is given credence.) Such a state did not engage in "assassination" if the targets were legitimately acquired in the course of self-defence.

Various arguments have been put forth from groups as diverse as the American Civil Liberties Union, former Republican Senator Ron Paul, and libertarians, that the Fifth Amendment - where no citizen shall be "deprived of life, liberty, or property, without due process of law" - is violated when such targeting of non-combatant American citizens is initiated without trial. Furthermore, the ACLU has argued that the CIA target list, being secret, is itself a violation of the due process clause (Miniter 2011).

The killing of US citizens by targeted drones strikes suggests the lengths the technological patriotism complex has gone. Lethal technologies can be used against "qualified" Americans, ersatz citizens who abridge their constitutional protections by virtue of conduct. Constitutional protections are suspended, and due process ultimately succumbs to the technological ease of elimination.

Such forms of Americanness were discussed by Senator Dianne Feinstein (D-Calif.), in questioning John Brennan, then President Barack Obama's nomination for the role of CIA director. Feinstein herself has taken the line that the use of lethal force against American citizens should be disclosed. "I have been calling for the public release of the administration's legal analysis on the use of lethal force - particularly against US citizens - for more than a year." (2013). The encounter showed the delicate manoeuvring currently taking place in the Senate about various forms of Americanness - at least in so far as it pertained to the use of unmanned vehicles. The drone program was being discussed, but transparency on the subject was out of the question. "One of the problems 
is, once the drone program is so public, and one American is caught up, people don't know much about this one 'American citizen' - so called” (Feinstein 2013).

Feinstein and Brennan proved oblique on the subject, but Anwar al-Awlaki, who died in a drone strike in Yemen in 2011, was one such "so-called" American, having been born in New Mexico. The constitutional clothing granted by that mere fact did not stop Feinstein pressing for a concerted disrobing, suggesting an old form of negating "Americanism" to accommodate the drone wars.

Indeed, Feinstein persisted in using the qualified American category, showing the ease with which constitutional rights can become moveable features of the political landscape, provided the circumstances are present. If you are an "American so called" then you are entitled to be exterminated in an extra-judicial drone strike. "When people hear 'American'," pressed Feinstein, "they think someone who's upstanding. And this man was not upstanding by a long shot."

A series of assumptions are being made here - what an "American" is, what such a vague term as "upstanding" might be, and what is done to disqualify the appellation. "They don't know the incitement he has stirred up," noted Feinstein. "I wonder if you could tell us a bit more about Mr. Awlaki and what he's been doing."

Brennan didn't disagree with the line of questioning Feinstein was taking, affirming that al-Awlaki was not merely a "propagandist" but "involved in activities that were designed to kill innocent men, women and children, mostly Americans." One's constitutional status as a US citizen could not be held against the use of executive orders. The debate within the Obama administration on targeting specific US citizens took place between a "war wing" (then CIA director Leon Panetta and Secretary of State Hillary Clinton) and the ACLU wing, represented by Attorney General, Eric Holder and other lawyers. The argument there was that, as Yemen was not in an authorised field of battle for the US, as opposed to Afghanistan, there could be no "battlefield exception". According to Miniter, "So, after a lot of thought and reflection, and the urging of Clinton and Panetta, the president decided to abandon Awlaki to the traitor's death that he deserved. Obama decided that the constitution gave the president the power to kill those who make war against the United States, even if they are citizens" (Miniter 2011).

The contradictory nature of the Congressional discussion can be gathered by the white paper obtained by Michael Isikoff of the NBC network and authored by the Department of Justice. The white paper titled "Lawfulness of a Lethal Operation Directed against a US citizen Who Is a Senior Operational Leader of Al-Qa'ida or An Associated Force" revealed the extensive qualifications on constitutional rights associated with American citizens deemed hostile the Republic (DOJ 2013). It emphasised the extra-territorial importance of the AUMF, that the United States is "in an armed conflict" with al-Qaida and its associated forces, and the seniority of the targets (DOJ 2013). "A use of force under such circumstances [those forces posing an imminent threat of violent attack against the United States] would be justified as an act of national self-defence" (DOJ 2013: 3). Drone strikes could take place "away from the zone of active hostilities," a consequence of seeing the nature of hostilities as part of a "non-international conflict".

The document goes on to claim that, "The Due Process Clause would not prohibit a lethal operation of the sort contemplated here." A calculus is imposed, one pitting the private interest of not having one's life taken against "the government's interest in waging war, protecting its citizens, and removing the threat posed by members of enemy forces". The "reality of combat" would render the use of force "necessary and appropriate," even against US citizens engaged in conflict against the United States (DOJ 2013: 5-6).

According to Amy Davidson, writing in The New Yorker, such reasoning resembled the apologetic language offered by John R. Stevenson in 1970 when, as a State Department legal advisor, he justified the Nixon administration's unsanctioned move into Cambodia ostensibly to combat Viet Cong and Northern Vietnamese forces. Indeed, Stevenson's legal summation regarding US actions in Cambodia is cited as a precedent that "the enemy" can be engaged from "a base in a new nation," which would bring it within the original armed conflict (DOJ 2013: 4 noting Stevenson 1970). Terms such as "imminent threat" and "capture is infeasible" become indistinguishable terms (Davidson 2013a). Emergencies dictate expediency.

President Obama similarly accepted a circumscribed version of American protections in his National Defence University address; the constitutional bar did not serve to protect US citizens from being targeted in times of armed conflict in distant, often inaccessible locations. The virtue of appropriately designed and adapted technology is noted in situations "where it would pose profound risks to our troops and local civilians". The operations in Pakistan "cannot be the norm." A conflict which did employ such weapons was part of "a just war - a war waged proportionally, in last resort, and in self-defence" (Obama 2013).

The Obama administration has subsequently revised the policy, granting the military exclusive rights to target American citizens, rather than the CIA itself. In February 2014, the discussion about whether an American would, 
in fact, be killed for purportedly arranging attacks on US citizens became public. In the words of Clive Stafford, director of Reprieve, a British-based human rights organisation, "It is a very sad day when US officials are squabbling in public over whether they should murder an American" (Al Jazeera and AP 2014).

There have also been attempts to bring officials behind the killing of al-Aulaqi, his son Abdulrahman and Samir Khan, all being US citizens, to book. This, it can be argued, is a form of a patriotic reassertion: the legal values of American citizenry tested before the courts in the face of the use of drone technology. Judge Rosemary Collyer of the US District Court for the District of Columbia accepted that the case was justifiable, even if the drone strike program emanated from the war making and national security powers of the executive and legislature (Nasser AlAulaqi v Leon Panetta 2014). In what can only be regarded as a formal acknowledgement of the extension of due process matters to the battlefield, the Judge did admit that the "interest in avoiding the erroneous deprivation of [the life of the subject] is uniquely compelling." Such constitutional deprivation could not have happened for either Abdulrahman, al-Aulaqi or Khan as their deaths arose in matters of negligence. The court did find, in terms of Anwar, that the complaint "states a 'plausible' procedural and substantive due process claim on behalf of Anwar al-Aulaqi."

The claim was, however, qualified. The extent that the violation is irremediable is emphasised by the justice's own view that, even if the government had violated Anwar al-Aulaqi's due process rights, there was "no available remedy under US law for this claim." Courts are reluctant to imply what is termed a Bivens claim, notably after alQaida and affiliate forces became the direct target of the 2001 Authorisation for Use of Military Force which was granted to the President. Despite finding for the government, Judge Collyer was not impressed by the "truculent opposition" to court requests for classified material showing Anwar al-Aulaqi as an enemy combatant, or that he was a member of al-Qaeda in the Arabian Peninsula.

A large issue at stake is that of evidence of culpability - the idea of imminent threat implied by the activity of such terrorist "targets." Drone warfare, by its nature, resists the evidentiary mould, a form of technology that makes the elimination of targets easier in times of emergency. With that in mind, modest proposals have been made to place the President "on firmer legal footing when using drones against American targets," in the words of George W. Bush's US Attorney-General Alberto R. Gonzales (2013). Gonzales, however, does not dispute the nature of what is a "state of war", though he does accept the Supreme Court's view that the President cannot act on a "blank check" on the issue of "the rights of the Nation's citizens" (Gonzales 2013: 59). Greater caution must be exercised. Such review, however, would only be a modest revision, constituting a possible false cover via legal oversight. Courts may well be ill-suited to assess claims in the realms of military necessity, unwittingly committing "a far graver sin to the rule of law in upholding patently unlawful uses of military force during wartime than those that resulted from such uses of force on their own" (Vladeck 2014: 28 noting Jackson 1944: 246).

The trend, however, is for the greater deployment of such weapons which continues to take place in a legal environment that has been left behind. Official reports from the UN Special Rapporteur on the use of armed drones have provided heftier guidelines that challenge the idea that "mere past involvement in planning attacks is sufficient to render an individual targetable even where there is no evidence of a specific and immediate attack". The use of such weapons in that sense "distorts the requirements established in international human rights law" (Heynes 2013: para 37; Emmerson 2014).

More subtle suggestions have also been advanced by such commentators as Micah Zenko, who argue that Washington should end signature strikes which target clearly identified militants on the basis of behavioural patterns and personal networks, and limit killings to a limited number of targets - terrorists, for instance, of transnational scope and ambition (Zenko 2012). While Zenko sees a role for such unmanned vehicles in security policies, he prefers to incorporate them within an international system of drafted norms and guidelines and the extension of law. Such views, however, suggest the fictitious cleanliness of such conflict, with its ease of regulation. In reality, they point to the continuing chaos of battlefield reality (Van Creveld 1985).

\section{| The Irresistibility of Drones}

Jeremy Rivkin has argued, unconvincingly, that the Obama presidency's conduct is symptomatic of an evolving tendency towards higher degrees of empathy. "The president has made empathy the core of his personal philosophy and the centrepiece of political decisions, from the conduct of his foreign policy to the selection of Supreme Court 
Justices" (Rivkin 2009: 177). The embrace of robotic technologies that further distance warriors from the scene of battle, desensitising policy makers to consequences, both domestic and international, as to how such technologies are used, suggests that the tendency is the reverse. Laws are not so much being undermined as being hollowed out by the deployment of such "cubicle warriors" and their machines.

In being fetishised, weaponised drones have become objects of faith, and the relationship between their operators, and the battlefield, distorted in a manner that amounts to a dire form of "misrecognition." Their defenders cite humanitarian grounds, and grounds of military necessity. Using such weapons has even served to override the protections offered by the American Constitution. Guilt or innocence is not a matter for due process in this case, but a mechanical resolution in an open-ended state of conflict. Military pre-emption, rather than a complex, sober assessment of past conduct, is what takes place. As Brennan himself explained, "None of those actions are to determine past guilt for those actions that they took. The decisions that they made are to take actions to prevent a future action - to protect American lives" (Davidson 2013b). Therein lies the self-fulfilling logic of extra-judicial killing: one is killing to prevent a dark future.

The modern technological state of surveillance, control and ordering of rights suggests qualifications to citizen's rights in the name of the secure society. What it also suggests is a radical project of hygienic, controlled killings that effectively deny the subject either human or legal status. "The expansive use of drones by the first States to acquire them, if not challenged," argues the UN Rapporteur, "can do structural damage to the cornerstones of international security and set precedents that undermine the protection of life across the globe in the longer term" (Heynes 2013: para 17). This is assisted by the nature of the violence. It is contained, and affected in distant spaces and territories. Public opinion will be less likely to be against such a clandestine, unknowing use of weapons against designated enemies, provided it takes place in the borderlands and outside any perceived harm's way to its users. Their lethality, to use the words of Boyer in describing the atomic bomb, has become a shield of protection for the Republic.

\section{Endnotes}

1.Senior Lecturer, School of Social, Urban and Global Studies, RMIT University, Melbourne.

2. References to the name vary, and are reproduced from the sources that mention that spelling.

3. School of Advanced Warfare, USMC, Student Requirements for the Middle East AY (1995-1996).

4. De Santana, "Nuclear Weapons as the Currency of Power," 343, making reference to Alexander Wendt, Social Theory of International Politics (Cambridge: Cambridge University Press, 1999), 109: "Neorealism "fetishizes' material capabilities in the sense that it imbues them with meanings and powers that 'can only correctly be attributed to human beings."
5. The literature debating those motivations is extensive. For a survey, see James S. Walker, "History, Collective Memory, and the Decision to Use the Bomb," Diplomatic History 19 (1995): 319-328; Barton Bernstein, "Truman and the A-Bomb: Targeting Noncombatants, Using the Bomb and his defending of the 'Decision,", ; Robert James Maddox, Weapons for Victory: The Hiroshima Decision Fifty Years Later (Columbia: University of Missouri Press, 1995); Samuel J. Walker, "Recent Literature on Truman's Atomic Bomb Decision: A Search for a Middle Ground," Diplomatic History 29, 2 (Apr., 2005): 311-334.

\section{References}

Al Jazeera and AP. 2014. "White House Considers Drone Strike Alperovitz, Gar. 1995. The Decision to Use the Atomic Bomb on US Citizen Abroad.” Feb 10. and the Architecture of an American Myth. New York: Knopf. 
Alston, Philip. 2010. Study on targeted killings, Report of the Special Rapporteur on extrajudicial, summary or arbitrary executions. Human Rights Council. 14/24/Add.6. http://www2. ohchr.org/english/bodies/hrcouncil/docs/14session/A. HRC.14.24.Add6.pdf. Accessed Jul 20, 2014.

Battista, Andrew. 2012. "Atomic Bombs and Drone Warfare." North of Centre (Lexington), Aug 2. http://noclexington. com/?p=7657. Accessed Dec 10, 2014.

Beattie, Missy. 2013. "Dream of the Drones" Counterpunch. Feb 15-17. http://www.counterpunch.org/2013/02/15/dream-ofthe-drones/. Accessed Jan 1, 2014.

Beres, Louis René. 2011. "After Osama bin Laden: Assassination, Terrorism, War, and International Law." Case Western Reserve Journal of International Law. 44, 1-2: 93-148.

Boyer, Paul S. 1994. By the Bomb's Early Light: American Thought and Culture at the Dawn of the Atomic Age, Chapel Hill: University of North Carolina Press.

Boyle, Michael J. 2013. “The Costs and Consequences of Drone Warfare." International Affairs. 89, 1: 1-29.

Burke, Anthony. 2004. "Just War or Ethical Peace? Moral Discourses of Strategic Violence after 9/11." International Affairs. 80, 2: 329-353.

Capaccio, Tony and Uday Mohan. 1995. “The Target." American Journalism Review. 10: 19-26.

Davidson, Amy. 2013a. "Which Americans are Targets?" The New Yorker. Feb 6.

. 2013b. "John Brennan and the 'So-called' Americans." The New Yorker. Feb 8.

De Santana, Anne Harrington. 2009. "Nuclear Weapons as the Currency of Power: Deconstructing the Fetishism of Force." Nonproliferation Review. 16, 3: 325-345.

DOD (US Department of Defence). 2007. Unmanned Systems Roadmap 2007-2032. Washington, D.C: US Department of Defence.

DOJ (US Department of Justice). 2013. "Lawfulness of a Lethal Operation Directed Against a US Citizen: Who is a Senior Operational leader of Al-Qa'ida or an Associate Force." White Paper. Feb. http://www.lawfareblog.com/wp-content/ uploads/2013/02/020413_DOJ_White_Paper.pdf. Accessed Feb 19, 2013.

Dower, John W. 2010. Cultures of War: Pearl Harbour/ Hiroshima/9-11/Iraq. New York: W. W. Norton.

1997. "Triumphal and Tragic Narratives of the War in Asia," in Laura Hein and Mark Selden, eds. Living With the Bomb: American and Japanese Cultural Conflicts in the Nuclear Age. New York: M.E. Sharpe, 37-51.

1996. "Three Narratives of Our Humanity" in Edward T. Linenthal and Tom Engelhardt, eds. History Wars: The Enola Gay and Other Battles for the American Past, New York: Metropolitan Books: 63-96.
1986. War without Mercy: Race and Power in the Pacific War. New York: Pantheon Books

Drake, Bruce. 2013. "Report questions drone use, widely unpopular globally, but not in the US," Oct 23. http://www. pewresearch.org/fact-tank/2013/10/23/report-questionsdrone-use-widely-unpopular-globally-but-not-in-the-u-s/. Accessed Jul 20, 2014.

Emmerson, Ben. 2014. Report of the Special Rapporteur on the promotion and protection of human rights and fundamental freedoms while countering terrorism, Ben Emmerson. A/HRC/25/59, Feb 28. http://justsecurity.org/wp-content/uploads/2014/02/Special-Rapporteur-RapporteurEmmerson-Drones-2014.pdf. Accessed Feb 10, 2015.

Feinstein, Diane. 2013. "Feinstein on Justice Department 'Lawfulness of Lethal Operation' Memo." Feb 5. http:// www.feinstein.senate.gov/public/index.cfm/press-releases?ID=f02275d9-7638-4613-b90b-3aa8c624eaf8. Accessed Feb 10, 2015.

Foust, Joshua and Ashley S. Boyle. 2012. "The Strategic Context of Lethal Drones." America Security Project, Perspective. Aug 16. http://www.scribd.com/doc/102744195/The-StrategicContext-of-Lethal-Drones. Accessed Feb 2, 2014.

Gonzales, Alberto R. 2013. “Drones: The Power to Kill," George Washington Law Review 82, 1: 1-60.

Gregory, Derek. 2014. "Drone Geographies.” Radical Philosophy. $183 \mathrm{Jan} /$ Feb. http://www.radicalphilosophy.com/article/ drone-geographies. Accessed Dec 1, 2014.

Heyns, Christof. 2013. Report of the Special Rapporteur on extrajudicial, summary or arbitrary executions, A/68/382 (September). http://justsecurity.org/wp-content/ uploads/2013/10/UN-Special-Rapporteur-ExtrajudicialChristof-Heyns-Report-Drones.pdf. Accessed Feb 15, 2015.

Hubbard, Bryan and Marouf A. Hasian. 1998. "The Generic Roots of the Enola Gay Controversy." Political Communication. 15, 4. Oct-Dec: 487-513.

Jackson, Robert H. (1944) Korematsu v United States, 324 US 214.

Kiernan, Denise. 2013. The Girls of Atomic City: The Untold Story of the Women Who Helped Win World War II. Waterville, Maine: Thorndike Press.

Kinchy, Abby J. 2009. "African Americans in the Atomic Age: Postwar Perspectives on Race and the Bomb, 1945-1947." Technology and Culture. 50, 2. Apr: 291-315.

Koh, Harold Hongju. 2010. "The Obama Administration and International Law." Annual Meeting of the American Society of International Law, Washington, D.C., Mar 25, www.state. gov/s/l/releases/remarks/139119.htm. Accessed Feb 16, 2015.

Lacquer, Thomas. 2011. "Something Fine and Powerful." London Review of Books. 33, 16. Aug. 25: 19-21

Linebaugh, Heather. 2013. "I worked on the US drone program." The Guardian. Dec 29. 
Linenthal, E. T. and T. Engelhart. 1996. History Wars: The Enola Gay and Other Battles for the American Past. New York: Holt.

Luckman, Robin. 1984. "Of Arms and Culture." Current Research on Peace and Violence. 7: 1-65.

MacMillan, A., Ken Booth, and Russell Trood (1999). "Strategic Culture," in Ken Booth and Russell Trood, eds. Strategic Cultures in the Asia Pacific Region, Basingstoke: Macmillan: $3-26$

Marx, Karl. 1982. "Capital” in Emile Burns, ed. The Marxist Reader. New York: Avenel Books.

Masco, Joseph. 2006. Nuclear Borderlands: The Manhattan Project in Post-Cold War New Mexico. Princeton: Princeton University Press.

Mazetti, Mark. 2013. The Way of the Knife: The CIA, a Secret Army, and a War at the Ends of the Earth. Harmondsworth: Penguin.

Meyer, Eugene L. 1995. "2 Exhibits to Mark A-Bombing." Washington Post, Jun 21: D1

Miller, Greg and Karen DeYoung. 2013. "Administration debates stretching 9/11 law to go after new al-Qaeda offshoots." The Washington Post. Mar 6.

Miniter, Richard. 2011. "Was Obama Right to Kill Awlaki?" The Daily Best, Sep 30.

Morely, Jefferson. 2012. “Air Force ramps up drone war." Salon. com. Apr 5.

Nasser Al-Aulaqi v Leon Panetta. 2014. Civil Action No 12-1192 (RMC). https://ecf.dcd.uscourts.gov/cgi-bin/show_public_ doc?2012cv1192-36. Accessed Dec 10, 2014.

Nobile, Philip. 1995. Judgment and the Smithsonian: The Bombing of Hiroshima and Nagasaki. New York: Marlowe and Company.

Obama, Barack. 2013. "Remarks by the President at the National Defense University." Fort McNair, Washington, D.C. May 23. https://www.whitehouse.gov/the-press-office/2013/05/23/remarks-president-national-defense-university. Accessed Jan 10, 2015.

Olsen, Gary. 2010. "Jeremy Rifkin's The Empathetic Civilization and P.W. Singer's Wired for War," ZCommunications.Org., Feb 9. http://www.zcommunications.org/jeremy-rifkin-s-the-empathic-civilization-and-p-w-singer-s-wired-for-war-by-gary-olson. Accessed Feb 9, 2014.

Paust, J. 2007. Beyond the Law: The Bush Administration's Unlawful Responses in the 'War' on Terror. Cambridge: Cambridge University Press.

Rifkin, Jeremy. The Empathetic Civilization: The Race to Global Consciousness in a World in Crisis. New York: Jeremy P. Tarcher/Penguin.

Roberts, Paul Craig. 2013. "America’s Expanding Kill List: Liberty is Disappearing Before Our Eyes.” CounterPunch. Feb 12.
Rogan, Tom. (2013) “In Defense of Drones." National Review Online. Oct 21.

Rengger, Nicholas. 2002. "On Just War Tradition in the 21st Century.” International Affairs. 78, 2: 353-363.

Sauer, Frank and Niklas Schörer. 2012. "Killer Drones: The 'Silver Bullet' of Democratic Warfare?" Security Dialogue. 43, 4: $363-380$

Shaw, Ian Graham Ronald and Majed Akhter. 2012. "The Unbearable Humanness of Drone Warfare in FATA, Pakistan.” Antipode. 44, 4: 1490-1509.

Singer, P. W. 2009. Wired for War: The Robotics Revolution and Conflict in the 21st Century. New York: Penguin.

Somerville, John. 1981. "Patriotism and War." Ethics. 91, 4: 568-578.

Stevenson, John R. 1970. Legal Adviser, Department of State. United States Military Action in Cambodia: Questions of International Law. Address before the Hammarskjold Forum of the Association of the Bar of the City of New York. May 28.

Strawser, Bradley Jay. "Moral Predators: The Duty to Employ Uninhabited Aerial Vehicles." Journal of Military Ethics. 9, 4: 342-368.

Snyder, Jack. (1977). The Soviet Strategic Culture: Implications for Limited Nuclear Operations, Santa Monica, CA: Rand.

Takaki, Ronald. 1995. Hiroshima: Why America Dropped the Atomic Bomb. Boston: Little, Brown, and Co.

The Economist. 2013. “America’s Killing Machine.” Apr 13.

United States Senate. 1995. Hearings before the Committee on Rules and Administration, United States Senate, One Hundred Fourth Congress: First Sessions on the Smithsonian Institution, management guidelines for the future. Hearings on May 11 and May 18.Washington, D.C.: US Government Printing Office.

Van Cleef, Marge. 2010. "Drone Warfare=Terrorism." Peace and Freedom. 70, 1: 20.

Van Creveld, Martin. 1985. Command in War. Cambridge, Mass: Harvard University Press.

1989. Technology and War: From 2000 B.C. to the Present. New York: Free Press.

Vladeck, Stephen I. 2014. "Targeted Killing and Judicial Review." George Washington Law Review. 82: 11-28.

Voice of America News. 2013. "Researcher: Most Civilian Drone Deaths 'From Faulty Information.” Mar 15.

Wittes, Benjamin. 2013. "Drones and the War on Terror: When Can the US Target Alleged American Terrorists Overseas?" Submission to the House Committee on the Judiciary. Feb 27. http://www.brookings.edu/research/testimony/2013/02/27-drones-terrorism-wittes. Accessed Feb 1, 2014. 
Wood, Jacob and Ken Harbaugh. 2014. "The Limits of Armchair Warfare.” New York Times, May 21.

Wyn Jones, Richard. 1999. Security, Strategy, and Critical Theory. Cambridge: Cambridge University Press.

Zenko, Micah. 2012. Reforming US Drone Strike Policies. New York: Council on Foreign Relations Press.

Žižek, Slavoj. 1989. The Sublime Object of Ideology. London and New York: Verso. 